\title{
Complementary/Alternative Medicine Experience in Cancer Patients: A Questionnaire-Based Survey
}

\author{
Gamze G. DOGU ${ }^{1}$, Aysegul KARGI ${ }^{2}$, Ozgur TANRIVERDI ${ }^{3}$, Arzu YAREN ${ }^{1}$, Gokcen DEMIRAY ${ }^{1}$, \\ Burcu Y. TASKOYLU ${ }^{1}$, Ahmet ERGIN ${ }^{4}$
}

\author{
${ }^{1}$ Pamukkale University Faculty of the Medicine, Department of Medical Oncology, Denizli, TURKEY \\ ${ }^{2}$ Denizli State Hospital, Division of Medical Oncology, Denizli, TURKEY \\ ${ }^{3}$ Mugla University Faculty of the Medicine, Department of Medical Oncology, Mugla, TURKEY \\ ${ }^{4}$ Pamukkale University Faculty of the Medicine, Department of Public Health, Denizli, TURKEY
}

\begin{abstract}
A study was designed to evaluate the frequency of complementary/alternative therapy (CAM) knowledge and usage in cancer patients. A 23-item survey questionnaire was administered to 494 patients who received chemotherapy in the medical oncology department of three hospitals between June 2011 and December 2011. After giving written informed consent, patients completed a selfadministered questionnaire. Differences among participants were assessed by using the SPSS 17.0 software. Of the 494 patients, $48 \%$ had heard of CAM, and $23.5 \%$ had used at least one CAM model. Herbs and vitamins were the most frequently used approach (82.2\%). The most commonly used herb was the stinging nettle $(55.5 \%)$. Marital status $(p=0.003)$, educational status $(p<0.001)$, monthly income $(p<0.001)$, knowledge about disease $(p<0.001)$, family history of comorbidity $(p<0.012)$, and place of residence (0.004) were statistically significant for knowledge about CAM. However, marital status $(p<0.001)$, comorbidity $(p=0.004)$, educational status $(p=0.006)$, family history of comorbidity $(p=0.008)$, and family history of cancer $(p=0.03)$ were statistically significant for CAM use. Logistic regression analysis showed that educational status $(p=0.015)$, high monthly income $(p=0.03)$, knowledge about disease $(p=0.005)$, and a family history of comorbidity $(p=0.005)$ were statistically significant for knowledge about CAM. Otherwise, only marital status $(p<0.001)$ and comorbidity $(p=0.04)$ were determined as independent factors for CAM use. Health professionals should routinely ask their patients about CAM use and discuss the reasons and outcomes of use. Randomized clinical trials are needed to determine possible risks and benefits associated with CAM use.
\end{abstract}

Keywords: Cancer, Complementary and alternative medicine

\section{ÖZET}

\section{Kanser Hastalarında Tamamlayıcı/Alternatif Tedavi: Bir Anket Çalışması}

Kanser hastalarında tamamlayıcı/alternatif tedaviyi (TAT) bilme ve kullanma sıklığını değerlendirmek için bu çalışma dizayn edildi. Haziran 2011 ile aralık 2011 tarihleri arasında, 3 hastanenin medikal onkoloji departmanında tedavi gören toplam 494 hastaya 23 soruluk bir anket uygulandı. Hastalara yazılı bilgilendirilmiş onam formu imzalatılıktan sonra, kendilerinin doldurması için anket formları verildi. Katılımcılar arasındaki farklar SPSS.17 paket programıla değerlendirildi. Toplam 494 hastanın \%48'i TAT terimini duymuş, \%23.5'। de en az bir TAT modelini kullanmıştı. Bitkiler ve vitaminler en sık kullanılan yaklaşımdı (\%82.2). En sık kullanılan bitki ise ısırgan otuydu (\%55.5). Medeni durum ( $p=0.003)$, eğitim durumu ( $p<0.001)$, aylık gelir düzeyi $(p<0.001)$, hastalığı bilme durumu $(p<0.001)$, ailede komorbidite varlığı $(p<$ 0.012) ve yaşadığı yer ( $(\mathrm{=}=0.004)$, TAT hakkında bilgi sahibi olma durumuyla istatistiksel olarak anlamlı bulundu. 
International Journal of Hematology and Oncology

Bununla beraber, TAT kullanımılla medeni durum ( $p<0.001)$, ek hastalık varlığı ( $p=0.004)$, eğitim durumu ( $p=0.006)$, ailede komorbidite varlığı $(p=0.008)$ ve ailede kanser varlığı $(p=0.03)$ istatistiksel olarak anlamlı bulundu. Lojistik regresyon analizi yapııdığında ise, eğitim durumu ( $p=0.015)$, yüksek aylık gelir düzeyi $(p=0.03)$, hastalık hakkında bilgi sahibi olma durumu ( $p=0.005)$, ailede komorbidite varlığı $(p=0.005)$ TAT hakkında bilgi sahibi olma durumuyla ilișkili idi. Sadece, medeni durum $(p<0.001)$ ve komorbidite varlığı $(p=$ 0.04) TAT kullanımıyla ilişkili olan bağımsız faktörler olarak saptandı. Sağlık çalışanları, rutin olarak hastalarına TAT kullanımını sormalı ve sebepleriyle kullanımdan kaynaklanabilecek sonuçları tartışmalıdır. TAT kullanımının olası risk ve faydalarını saptamaya yönelik randomize çalışmalara intiyaç vardır.

Anahtar Kelimeler: Kanser, Tamamlayıc//alternatif tedavi

\section{INTRODUCTION}

Patients diagnosed with cancer have many different problems. Currently, many types of cancer can be treated successfully. Unfortunately, some advanced stage cancers are managed only with palliation. If patients decide to be treated with modern oncological therapy, some side effects and treatment failure will likely develop. Then, patients can feel as though they have no options left. At this point, the use of complementary and alternative medicine (CAM) becomes a part of therapy.

As defined by the National Center for Complementary and Alternative Medicine (NCCAM), CAM includes "a group of diverse medical and healthcare systems, practices, and products that are not presently considered to be part of conventional medicine". ${ }^{1}$ This term may be included in two different meanings. One of them is "complementary medicine," which describes the use of CAM in concurrence with conventional medicine, while the other term is "alternative medicine" and refers to the use of therapies in place of conventional medicine.

Usually, cancer patients use complementary and alternative medicine in addition to modern medicine. Among cancer patients, CAM is considered as natural, non-toxic, and has health promoting effects. ${ }^{2,3}$ Therefore, CAM is very popular among cancer patients and gives them hope for a cure. In addition, these patients want to try all therapies other than modern therapies.

CAM includes a wide range of methods and therapy categories. According to the National Center for Complementary and Alternative Medicine, CAM therapies classify into four categories ${ }^{1}$ :

1. Natural products and supplements, such as herbal medicines (botanicals), vitamins, and minerals

2. Mind-body interventions like meditation, yoga, acupuncture, prayer, mind and body practices (deepbreathing exercises, hypnotherapy, progressive relaxation, qi gong)
3. Manipulations and body-based methods like chiropractic, osteopathic manipulation, and massage

4. Others such as energy therapies (magnet therapy, light therapy, qi gong, Reiki, healing touch) and alternative medical systems, including traditional Chinese Medicine and Ayurveda etc.

Medical traditional methods in Turkey date back to ancient times in Anatolia, also known as Asia Minor. ${ }^{4}$ CAM is practiced almost exclusively by people who are not educated in conventional medicine. CAM practices cover a wide spectrum, ranging from herbal prescriptions, religious practices such as "muska (script writing)" or "ufleme (touch and pay)," to "old woman medicine" practices such as drinking turtle blood or eating the flesh of a mole (Talpidae)5. Institutions called "Ocak" in Turkish, where a form of CAM is practiced to cure a multitude of diseases, fractures, and dislocations, exist at numerous locations in Anatolia. A sort of alternative medical practitioner called "Ocakli" (folk physicians) perform CAM functions in these places. CAM also involves therapy through nonconventional drugs, which are mostly of herbal origin and at times animal or inorganic. ${ }^{5}$ However, medical practice in Turkey is modern medicine.

It is important to know the types of CAM that cancer patients are using. Some of these modalities/therapies have important toxicities and can be dangerous in combination with chemotherapy. Therefore, a questionnaire-based survey was performed to understand frequency, knowledge, and demographics of CAM usage in our cancer patients.

\section{METHODS}

Patient Population and Procedures: This study was conducted on adult (18 years of age or older) patients diagnosed with cancer who attended ambulatory patient care units at the three hospitals in their Department of Medical Oncology, from June 2011 to December 2011. Patients who were too ill (performance status) to complete the interview were excluded. The 
International Journal of Hematology and Oncology

\begin{tabular}{|c|c|c|c|c|c|}
\hline Characteristics & & Yes, n (\%) & No, n (\%) & Total, n (\%) & $\mathbf{p}$ \\
\hline \multicolumn{6}{|l|}{ Age } \\
\hline & $<40$ & $17(44.7)$ & 21 (55.3) & $38(100)$ & 0.09 \\
\hline & $40-50$ & 45 (55.6) & $36(44.4)$ & $81(100)$ & \\
\hline & $50-60$ & $79(56.4)$ & $61(43.6)$ & $140(100)$ & \\
\hline & 60 & $96(44.4)$ & $120(55.6)$ & $216(100)$ & \\
\hline \multicolumn{6}{|l|}{ Gender } \\
\hline & Female & $125(50.4)$ & $123(49.6)$ & $248(100)$ & 0.81 \\
\hline & Male & 112 (49.3) & $115(50.7)$ & $227(100)$ & \\
\hline \multicolumn{6}{|l|}{ Martial Status } \\
\hline & Married & 208 (51.9) & $193(48.1)$ & $136(100)$ & $0.003^{\star}$ \\
\hline & Single & $5(18.5)$ & $22(81.5)$ & $27(100)$ & \\
\hline & Divorced & $24(52.2)$ & $22(50)$ & $474(100)$ & \\
\hline \multicolumn{6}{|c|}{ Place of residence } \\
\hline & Urban & $130(57)$ & $98(43)$ & 228(100) & $0.004^{*}$ \\
\hline & Rural & $106(43.6)$ & $137(56.4)$ & $243(100)$ & \\
\hline \multicolumn{6}{|c|}{ Educational status } \\
\hline & Illiterate & $13(44.8)$ & $16(55.2)$ & $29(100)$ & $<0.001^{*}$ \\
\hline & Primary school & $138(43.9)$ & $176(56.1)$ & $314(100)$ & \\
\hline & Junior high school & $17(48.6)$ & $18(51.6)$ & $35(100)$ & \\
\hline & High School & $34(63.0)$ & $20(37.0)$ & $54(100)$ & \\
\hline & University & $35(81.4)$ & $8(18.6)$ & $43(100)$ & \\
\hline \multicolumn{6}{|l|}{ Insurance } \\
\hline & Medicare for civil servant & $68(50)$ & $68(50)$ & $136(100)$ & 0.98 \\
\hline & Medicare for worker & $147(50.2)$ & $146(49.8)$ & 293 (100) & \\
\hline & Private & $4(57.1)$ & $3(42.9)$ & $7(100)$ & \\
\hline & Other & $17(51.5)$ & $16(48.5)$ & $33(100)$ & \\
\hline \multicolumn{6}{|l|}{ Profession } \\
\hline & Housewife & $93(45.8)$ & $110(54.2)$ & $203(100)$ & 0.25 \\
\hline & Worker & $15(50)$ & $15(50)$ & $30(100)$ & \\
\hline & Self-employed & $20(57.1)$ & $15(42.9)$ & $35(100)$ & \\
\hline & Farmer & $17(41.5)$ & 24 (58.5) & $41(100)$ & \\
\hline & Civil servant & $60(58.8)$ & $42(41.2)$ & $102(100)$ & \\
\hline & Retired & $32(50.8)$ & $31(49.2)$ & $63(100)$ & \\
\hline \multicolumn{6}{|l|}{ Comorbidity } \\
\hline & Yes & $77(47)$ & $87(53)$ & $164(100)$ & 0.33 \\
\hline & No & $158(51.6)$ & $148(48.4)$ & $306(100)$ & \\
\hline \multicolumn{6}{|c|}{ Family history of comorbidity } \\
\hline & Yes & $114(56.4)$ & $88(43.6)$ & $202(100)$ & $0.012^{\star}$ \\
\hline & No & $120(44.8)$ & $148(55.2)$ & $268(100)$ & \\
\hline \multicolumn{6}{|c|}{ Family history of cancer } \\
\hline & Yes & $78(52.0)$ & $72(48.0)$ & $150(100)$ & 0.53 \\
\hline & No & 158 (48.9) & $165(51.1)$ & $323(100)$ & \\
\hline \multicolumn{6}{|c|}{ Knowledge about disease } \\
\hline & Yes & $223(53.5)$ & $194(46.5)$ & $417(100)$ & $<0.001^{*}$ \\
\hline & No & $9(20.5)$ & $35(79.5)$ & $44(100)$ & \\
\hline \multicolumn{6}{|l|}{ Monthly income } \\
\hline & $<\mathrm{MW}$ & $42(35.9)$ & $75(64.1)$ & $117(100)$ & $<0.001^{\star}$ \\
\hline & MW up to 2 times MW & 146 (53.3) & $128(46.7)$ & $274(100)$ & \\
\hline & $>2$ times $\mathrm{MW}$ & $26(81.3)$ & $6(18.8)$ & $32(100)$ & \\
\hline & Social relief & $19(44.2)$ & $24855.8)$ & $43(100)$ & \\
\hline
\end{tabular}

questionnaires were handed out to the patients by their nurses on arrival at the hospital as outpatients. Informed consent was obtained from all patients. It was explained to the patients that all information offered would be treated confidentially, and that refusal

UHOD Number: 1 Volume: 24 Year: 2014 to participate in the study would not jeopardize their care in any way.

Questionnaire: The questionnaire was in Turkish and consisted of 23 questions. Most of them were multiple-choice questions; however, the patients were 
International Journal of Hematology and Oncology

Table 2. Sociodemographic Characteristics of patients who had used or not CAM

\begin{tabular}{|c|c|c|c|c|}
\hline Characteristics & Yes, n (\%) & No, n (\%) & Total, n (\%) & $\mathbf{p}$ \\
\hline \multicolumn{5}{|l|}{ Age } \\
\hline$<40$ & $11(30.6)$ & $25(69.4)$ & $36(100)$ & 0.83 \\
\hline $40-50$ & $18(22.8)$ & $61(77.2)$ & $79(100)$ & \\
\hline $50-60$ & $35(25.4)$ & $103(74.6)$ & $138(100)$ & \\
\hline 60 & $52(24.3)$ & $162(75.7)$ & $216(100)$ & \\
\hline \multicolumn{5}{|l|}{ Gender } \\
\hline Female & $59(24.7)$ & $180(75.3)$ & $239(100)$ & 0.93 \\
\hline Male & $57(25.0)$ & $171(75.0)$ & $228(100)$ & \\
\hline \multicolumn{5}{|l|}{ Martial Status } \\
\hline Married & $92(23.3)$ & $303(76.7)$ & 395 (100) & $<0.001^{*}$ \\
\hline Single & $17(63.0)$ & $10(37.0)$ & $27(100)$ & \\
\hline Divorced & $7(15.6)$ & $38(84.4)$ & $45(100)$ & \\
\hline \multicolumn{5}{|l|}{ Place of residence } \\
\hline Urban & $62(27.4)$ & $164(72.6)$ & $226(100)$ & 0.19 \\
\hline Rural & $53(22.3)$ & $185(77.7)$ & $228(100)$ & \\
\hline \multicolumn{5}{|l|}{ Educational status } \\
\hline Illiterate & $4(14.8)$ & $23(85.2)$ & $27(100)$ & $0.006^{*}$ \\
\hline Primary school & $76(24.4)$ & $235(75.6)$ & $311(100)$ & \\
\hline Junior high school & $16(48.5)$ & $17(51.5)$ & $33(100)$ & \\
\hline High School & $8(15.1)$ & $45(84.9)$ & $53(100)$ & \\
\hline University & $12(27.9)$ & $31(72.1)$ & $43(100)$ & \\
\hline \multicolumn{5}{|l|}{ Insurance } \\
\hline Medicare for civil servant & $37(27.6)$ & $97(72.4)$ & $134(100)$ & 0.40 \\
\hline Medicare for worker & $66(22.7)$ & $225(77.3)$ & $291(100)$ & \\
\hline Private & $3(42.9)$ & $4(57.1)$ & $7(100)$ & \\
\hline Other & $9(30.0)$ & $21(70.0)$ & $30(100)$ & \\
\hline \multicolumn{5}{|l|}{ Profession } \\
\hline Housewife & 49 (24.9) & $148(75.1)$ & $197(100)$ & 0.25 \\
\hline Worker & $12(41.4)$ & $17(58.6)$ & $29(100)$ & \\
\hline Self-employed & $9(25.7)$ & $26(74.3)$ & $35(100)$ & \\
\hline Farmer & $12(29.3)$ & $29(70.7)$ & $41(100)$ & \\
\hline Civil servant & $19(19.0)$ & $81(81.0)$ & $100(100)$ & \\
\hline Retired & $15(23.4)$ & 49 (76.6) & $64(100)$ & \\
\hline \multicolumn{5}{|l|}{ Comorbidity } \\
\hline Yes & $51(32.1)$ & $108(67.9)$ & $159(100)$ & $0.004^{*}$ \\
\hline No & $61(20.1)$ & $243(79.9)$ & $304(100)$ & \\
\hline \multicolumn{5}{|l|}{ Family history of comorbidity } \\
\hline Yes & $61(30.5)$ & $139(69.5)$ & $200(100)$ & $0.008^{*}$ \\
\hline No & $52(19.8)$ & $211(80.2)$ & $263(100)$ & \\
\hline \multicolumn{5}{|l|}{ Family history of cancer } \\
\hline Yes & $45(30.6)$ & $102(69.4)$ & $147(100)$ & $0.03^{*}$ \\
\hline No & $69(21.8)$ & $248(78.2)$ & $317(100)$ & \\
\hline \multicolumn{5}{|l|}{ Knowledge about disease } \\
\hline Yes & $96(23.5)$ & $312(76.5)$ & $408(100)$ & 0.42 \\
\hline No & $8(18.2)$ & $36(81.8)$ & $44(100)$ & \\
\hline \multicolumn{5}{|l|}{ Monthly income } \\
\hline$<\mathrm{MW}$ & $29(25.0)$ & $87(75.0)$ & $116(100)$ & 0.67 \\
\hline MW up to 2 times MW & $64(23.5)$ & $208(76.5)$ & $272(100)$ & \\
\hline$>2$ times $M W$ & $11(33.3)$ & $22(66.7)$ & $33(100)$ & \\
\hline Social relief & $9(23.7)$ & $29(76.3)$ & $38(100)$ & \\
\hline
\end{tabular}




\begin{tabular}{|c|c|c|c|c|}
\hline Characteristics & Yes, n (\%) & No, $n(\%)$ & Total, n (\%) & $\mathbf{p}$ \\
\hline \multicolumn{5}{|l|}{ Site of cancer } \\
\hline Breast cancer & $32(25.2)$ & $95(74.8)$ & $127(100)$ & 0.60 \\
\hline Respiratory system & $37(27.8)$ & $96(72.2)$ & $133(100)$ & \\
\hline Gastrointestinal system & $27(20.5)$ & 105 (79.5) & $132(100)$ & \\
\hline Genitourinary system & $12(27.9)$ & $31(72.1)$ & $43(100)$ & \\
\hline Others & $8(25.0)$ & $24(75.0)$ & $32(100)$ & \\
\hline \multicolumn{5}{|l|}{ Stage of disease } \\
\hline Metastatic & $66(23.7)$ & $212(76.3)$ & $278(100)$ & 0.50 \\
\hline Non-metastatic (early an & dvanced) & $50(26.5)$ & $139(73.5)$ & $189(100)$ \\
\hline \multicolumn{5}{|c|}{ Type of therapy (before chemotherapy) : Surgery } \\
\hline Yes & $47(25.4)$ & $138(74.6)$ & $185(100)$ & 0.81 \\
\hline No & $69(24.5)$ & $213(75.5)$ & $282(100)$ & \\
\hline \multicolumn{5}{|c|}{ Type of therapy( before chemotherapy ): Radiotherapy } \\
\hline Yes & $71(25.4)$ & $209(74.6)$ & $280(100)$ & 0.75 \\
\hline No & $45(24.1)$ & $142(75.9)$ & $187(100)$ & \\
\hline \multicolumn{5}{|l|}{ BMI (Body mass index) } \\
\hline$<18.5$ & $3(15.0)$ & $17(85.0)$ & $20(100)$ & 0.32 \\
\hline $18.5-24.9$ & $45(24.9)$ & $136(75.1)$ & $181(100)$ & \\
\hline $25.0-29.9$ & $48(28.9)$ & $118(71.1)$ & $166(100)$ & \\
\hline$\geq 30.0$ & $17(20.2)$ & $67(79.8)$ & $84(100)$ & \\
\hline
\end{tabular}

allowed to add further comments. The questionnaire was structured to recover socio-demographic data (age, gender, place of residence, education, income, marital status, profession, family history of chronic disease and cancer, comorbidity, and level of information about disease) and details pertaining to use of CAM among our patients and patient-healthcare staff relations (to share the use of CAM with health professionals). Medical data included diagnosis, stage at diagnosis, current or previous specific anticancer treatment modalities, and body-mass index.

\section{Statistical Analysis}

The data were recorded and analyzed using SPSS for Windows, version 17.0 software (SPSS, Inc., Chicago, IL). The $\mathrm{X}^{2}$ test was used for comparisons between demographic groups. For all statistical analyses, a two-sided p-value of 0.05 was considered sta- tistically significant. Comparisons were assessed by a $\mathrm{X}^{2}$ test. Logistic regression analysis was used to analyze potential variables that may have independently influenced the use of CAMs.

\section{RESULTS}

The study population consisted of 494 patients, comprised of 258 women $(52.2 \%)$ and 236 men $(47.8 \%)$. The median age was 58 years, ranging from 24 to 90 years. Socio-demographic characteristics of patients are given in Tables 1 and 2. Table 1 shows patients who had knowledge about CAM therapies, and Table 2 shows the socio-demographic features about CAM use. Table 3 shows the clinical characteristics of patients who used CAM.

Marital status $(\mathrm{p}=0.003)$, educational status $(\mathrm{p}<$ $0.001)$, monthly income $(\mathrm{p}<0.001)$, knowledge about the disease $(\mathrm{p}<0.001)$, family history of comorbid- 


\begin{tabular}{|c|c|c|}
\hline & $\mathbf{n}$ & $\%$ \\
\hline \multicolumn{3}{|l|}{ Type of CAM } \\
\hline Herbal & 113 & 67.3 \\
\hline Vitamins, & 25 & 14.9 \\
\hline $\begin{array}{c}\text { Talk to another person (friends } \\
\text { patients, imam, hodja etc.) }\end{array}$ & 18 & 6.0 \\
\hline \multicolumn{3}{|l|}{ Meditation, yoga, acupuncture } \\
\hline massage prayer & 10 & 10.7 \\
\hline \multicolumn{3}{|l|}{ Other ( Energy therapies, } \\
\hline bioenergy, etc) & 2 & 1.1 \\
\hline \multicolumn{3}{|l|}{ Type of plant } \\
\hline \multicolumn{3}{|l|}{ Stinging nettle with without various } \\
\hline herbal agents & 126 & 55.5 \\
\hline Pomegranate juice & 23 & 10.1 \\
\hline Raisins & 61 & 26.9 \\
\hline Others & 17 & 7.5 \\
\hline \multicolumn{3}{|l|}{ Advised to use } \\
\hline Family & 54 & 32.9 \\
\hline Friends & 56 & 34.1 \\
\hline Patients & 15 & 9.1 \\
\hline Health professionals & 39 & 23.9 \\
\hline \multicolumn{3}{|l|}{ Type of supply } \\
\hline Shopping & 57 & 54.3 \\
\hline Internet & 11 & 10.5 \\
\hline Other & 37 & 35.2 \\
\hline
\end{tabular}

Do you believe that the method you use will be useful for your treatment?

$\begin{array}{lll}\text { Yes } & 126 & 61.8\end{array}$

$\begin{array}{lll}\text { No } & 78 \quad 38.2\end{array}$

Reason for CAM usage

No benefited from convensional therapy $21 \quad 15.8$

$\begin{array}{lll}\text { To add benefit to modern therapy } & 53 & 39.8\end{array}$

$\begin{array}{lll}\text { Advised } & 48 & 36.1\end{array}$

$\begin{array}{lll}\text { Other } & 11 & 8.3\end{array}$

To share the use of CAM with doctor

$\begin{array}{lll}\text { Yes } & 81 & 51.9\end{array}$

$\begin{array}{lll}\text { No } & 75 & 48.1\end{array}$

Cooperation between CAM users and healty professionals Yes 81 51.9

$\begin{array}{lll}\text { No } & 75 & 48.1\end{array}$

Has your nurse/medical staff received information about CAM?

Yes

$246 \quad 78.6$

No

$67 \quad 21.4$ ity $(\mathrm{p}<0.012)$, and place of residence $(0.004)$ were statistically significant for knowledge about CAM. But no significant difference was found between who had knowledge about CAM and who had not heard of $\mathrm{CAM}$, with respect to age, gender, insurance, profession, comorbidity, and family history of cancer ( $\mathrm{p}>$ $0.05)$.

Of the 494 patients, 237 patients (23.5\%) had used at least one type of CAM since the time of diagnosis. Marital status $(p<0.001)$, comorbidity $(p=0.004)$, educational status $(\mathrm{p}=0.006)$, family history of comorbidity $(\mathrm{p}=0.008)$, and family history of cancer $(p=0.03)$ were statistically significant for CAM use. However, age, gender, place of residence, insurance, profession, and comorbidity were not statistically significant ( $>0.05$ ). Additionally, type of cancer, stage of disease, type of therapy (radiotherapy, surgery), and BMI (Body mass index) were not statistically significant either.

The most frequently used methods were herbal therapy (67.3\%) and vitamins (14.9\%) (Table 4). The most commonly used herb was the stinging nettlealone or in combination (55.5\%). The second plant type was raisins $(26.9 \%)$. CAM agents were generally combined with conventional anti-cancer agents. Agents could easily be obtained from regular herbal stores (or the internet) at a suitable price. Our patients usually prefer to shop from stores $(54.3 \%)$ versus the internet $(10.5 \%)$. Interestingly, almost half our patients consulted their physicians about CAM use (51.9\%) (Table 4).

Logistic regression analysis showed that educational status $(\mathrm{p}=0.015)$, high monthly income $(\mathrm{p}=0.03)$, knowledge about the disease $(\mathrm{p}=0.005)$, and family history of comorbidity $(\mathrm{p}=0.005)$ were statistically significant for knowledge about CAM. Otherwise, only marital status $(\mathrm{p}<0.001)$ and comorbidity $(\mathrm{p}=$ 0.04 ) were determined as independent factors for CAM use (Tables 5 and 6).

We also found that $78.6 \%$ of patients had information about CAM before using it, $34.1 \%$ got advice from friends, and $39.8 \%$ of patients believed that adding it to modern therapy created a beneficial effect.

\section{DISCUSSION}

The increasing interest in CAM among cancer patients may be due to the limitations of conventional cancer therapy. ${ }^{6}$ There is an increased concern about 


\begin{tabular}{|c|c|c|c|}
\hline Characteristics & Odds Ratio & $95 \% \mathrm{Cl}$ & $\mathbf{P}$ \\
\hline Educational Status & & & 0.015 \\
\hline Primary school & 0.703 & $0.313-1.580$ & 0.394 \\
\hline Junior high school & 1.490 & $0.472-4.709$ & 0.497 \\
\hline High school & 1.138 & $0.427-3.031$ & 0.797 \\
\hline University & 2.597 & $0.832-8.109$ & 0.100 \\
\hline Illiterate & $\mathrm{R}$ & & \\
\hline Monthly income & & & 0.09 \\
\hline$<\mathrm{MW}$ & 0.717 & $0.333-1.541$ & 0.394 \\
\hline MW up to 2 times MW & 1.351 & $0.670-2.727$ & 0.401 \\
\hline$>2$ times MW & 3.509 & $1.115-11.045$ & 0.032 \\
\hline Social relief & $\mathrm{R}$ & & \\
\hline Knowledge about disease & 3.107 & $1.410-6.844$ & 0.005 \\
\hline Family history of comorbidity & 1.798 & $1.192-2.710$ & 0.005 \\
\hline
\end{tabular}

the use of CAM by oncology patients because potential adverse drug interactions could cause patients to experience increased toxicity or decrease the efficacy of the conventional systemic therapy used to treat cancer. $^{7}$

Ernest and Cassileth summarized 26 studies from 13 countries in adult populations and reported that the frequency of using CAM methods varies from $9 \%$ to $64 \%$ in patients with cancer. In developed countries, CAM is used by $25 \%$ to $50 \%$ of the general population8. Our result is within the normal range (23.5\%).

In our patients, CAM use was generally limited to herbal remedies, the most frequent ingredient being the nettle. The use of other known CAM approaches was minimal. The possible explanation for this behavior is being less educated, having a lower income, and a 'traditional society structure'.,3,9 In Turkish culture, the most commonly used herb is reported as nettle leaves/teas and thyme, often mixed with other compounds. Availability is very easy and has a suitable price. Moreover, many people use herbal therapy because of the belief that natural products are safe and the combination with the other therapies is harmless, etc. However, some studies showed that these products do have toxic effects.

TABLE 6.Logistic regression analysis of demographic and clinic determinants of CAM use ${ }^{\star \star \star}$

\begin{tabular}{|llll} 
Characteristics & Odds Ratio & $\mathbf{9 5 \%} \mathbf{C l}$ & $\mathbf{P}$ \\
\hline Martial Status & & & $<0.001$ \\
Married & 1.54 & $0.66-3.61$ & 0.31 \\
Single & 8.06 & $2.59-25$ & $<0.001$ \\
Divorced & $\mathrm{R}$ & & \\
Comorbidity & 1.6 & $1.01-2.54$ & 0.04
\end{tabular}

*** Statistical analyses did not reveal significant differences for the other parameters ( including family history of cancer, family history of comorbidity and educational status) 
The prevalence of CAM use by ethnicity has been studied. A San Francisco-based study found that African-American women used spiritual healing more frequently than other types of CAM (36\%), Chinese women most often reported using herbal remedies (22\%), and Latino women used dietary therapies (30\%) and spiritual healing (26\%). ${ }^{10}$

Moreover, Richardson et al. reported a group of mixed cancer patients used CAM because patients hoped to improve their quality of life (77\%), boost their immune system (71\%), and prolong their life $(62 \%) .{ }^{11}$ An Italian study showed that patients' main reasons for using CAM were physical distress $(61 \%)$ and psychological distress $(21 \%) .{ }^{12}$ In our study, patients said they used CAM because of "adding benefit to medical therapy" (39.8\%), "advised" (36.1\%), and "uselessness of conventional therapy" (15.8\%). Although there were a high proportion of Turkish patients stating that CAM techniques were not effective in both the studies done by Ceylan et al. and Samur et al. (46.8\% and $48.0 \%$, respectively), our study revealed $38.2 \%$ of patients stating that CAM was not effective. ${ }^{5,13}$ But Ucan et al. (20.7\%) and Tas et al. (7.4\%) reported a low percentage of patients stating that CAM techniques were not effective., ${ }^{2,3}$ It may be due to our patients having low educational levels. Only $20 \%$ of patients graduated from high school and university. Maybe they did not know how to use the internet.

The socio-demographic factors associated with CAM usage are confirmed by some studies. Patients who are female, younger, and have higher educational levels are more likely to use CAM..$^{11,14-16}$ In our study, multivariate logistic regression analysis showed that only educational status was statistically significant to knowledge about CAM, but we did not correlate the use of CAM ( $\mathrm{p}=0.015, \mathrm{p}>0.05$, respectively).

In support of other studies, we found that marital status was associated with CAM usage $(\mathrm{p}<0.001){ }^{17,18}$ We also found that comorbidity was statistically significant. Thus, marital status and comorbidity were determined as independent factors for CAM use. It is possible that these patients may be used to other medications and our patients like to take medicine $(\mathrm{p}=0.04)$.

Cooperation between CAM users and medical staff concerning CAM usage was strong in our study (51.9 $\%$ of the patients). However, some Turkish studies reported that CAM usage was weak in cooperation2,3.
Many studies showed that patients using CAM learned about this treatment from friends and family. ${ }^{2,3,19-21}$ We also found the same result in our study. However, $23.9 \%$ of the patients reported that they learned about CAM from health professionals in the media.

Health professionals need to be able to provide information about CAM to their patients and documentation of CAM use should become part of routine assessment for all cancer patients. Physicians who are willing to communicate openly and in a nonjudgmental style about CAM may avoid disrupting the patient-medical staff relationship and possibly encourage compliance with conventional treatment6.

Studies show that some herbs, such as feverfew, garlic, ginger, and gingko can cause bleeding complications and have been associated with life-threatening perioperative bleeding. ${ }^{22}$ Some herbs have been associated with liver toxicity that may be particularly dangerous in combination with certain chemotherapies. ${ }^{23,24}$ Few herbs are tested for side effects, quality control, or contamination.

Patient-doctor/medical staff communication and patient education about CAM should be improved. The oncology community must be willing to communicate with patients about CAM, inform them about possible contraindications or benefits, and participate in research to answer questions of safety and efficacy. Patient expectations, psychological reactions, acceptance of health status, and cost and clinical outcomes pertaining to the medical treatment should be evaluated properly. Further large-scale studies are required.

\section{REFERENCES}

1. NCCAM. What is complementary and alternative medicine (CAM)? National Center for Complementary and Alternative Medicine website. Available at: http://nccam.nih.gov/health/ whatiscam/\#6. Accessed May 1, 2007.

2. Ucan O, Pehlivan S, Ovayolu N, etal. The use of complementary therapies in cancer patients: a questionnairebased descriptive survey from southeastern Turkey. Am J Clin Oncol 31: 589-94, 2008.

3. Tas F, Ustuner Z, Can G, et al. The prevalence and determinants of the use of complementary and alternative medicine in adult Turkish cancer patients. Acta Oncol 44: 161-167, 2005.

4. Acıpayamlı O. Folk medicine in Turkish folklore (Article in Turkish). Dtcfder 26: 1-2, 1969. 
5. Ceylan S, Hamzaoglu O, Komurcu S, et al. Survey of the use of complementary and alternative medicine among Turkish cancer patients. Complement Ther Med 10: 94-99, 2002.

6. Richardson MA, Sanders T, Palmer JL, Greisinger A, Singletary SE. Complementary/alternative medicine use in a comprehensive cancer center and the implications for oncology. J Clin Oncol 18: 2505-2514, 2000;

7. Navo MA, Phan J, Vaughan C, et al. An assessment of the utilization of complementary and alternative medication in women with gynecologic or breast malignancies. J Clin Oncol 22: 671-677, 2004.

8. Milazzo S, Ernst E. Newspaper coverage of complementary and alternativ therapies for cancer-UK 2002-2004. Support Care Cancer 14: 885-889, 2006.

9. Turkdogan O. Culture and Health Disease System (article in Turkish). MEB Publications 1991: 145-147.

10. Lee MM, Lin SS, Wrensch MR, et al. Alternative therapies used by women with breast cancer in four ethnic populations. J Natl Cancer Inst 92: 42-47, 2000.

11. Richardson MA, Sanders T, Palmer JL, et al. Complementary/ alternative medicine use in a comprehensive cancer center and the implications for oncology. J Clin Oncol 18: 2505-2514, 2000.

12. Crocetti E, Crotti N, Feltrin A, et al. The use of complementary therapies by breast cancer patients attending conventional treatment. Eur J Cancer 34: 324-328, 1998.

13. Samur M, Bozcuk HS, Kara A, et al. Factors associated with utilization of nonproven cancer therapies in Turkey. Support Care Cancer 5: 452-458, 2001.

14. Molassiotis A, Fernadez-Ortega P, Pud D, et al. Use of complementary and alternative medicine in cancer patients: a European survey. Ann Oncol 16: 655-663, 2005.

15. Zollman C, Vickers A. ABC of complementary medicine. Users and practitioners of complementary medicine. Br Med $\mathrm{J}$ 319: 836-838, 1999.

16. Eisenberg DM, Davis RB, Ettner SL, et al. Trends in alternative medicine use in United States, 1990-1997. JAMA 280: 1569-1575, 1998.

17. Munstedt K, Kirsch K, Milch W, et al. Unconventional cancer therapy: Survey of patients with gynecological malignancy. Arch Gynecol Obstet 258: 81-88, 1996.
18. Crocetti E, Crotti N, Feltrin A, et al. The use of complementar therapies by breast cancer patients attending conventional treatment. Eur J Cancer 34: 324-328, 1999.

19. Swisher EM, Cohn DE, Goff BA, et al. Use of complementary and alternative medicine among women with gynecologic cancers. Gynecol Oncol 84: 363-367, 2002.

20. Algier LA, Hanoglu Z, Ozden G, et al. The use of complementary and alternative (non-conventional) medicine in cancer patients in Turkey. Eur J Oncol Nurs 9: 138-146, 2005.

21. Scott JA, Kearney N, Hummerston S, et al. Use of complementary and alternative medicine in patients with cancer: a UK survey. Eur J Oncol Nurs 9: 131-137, 2005.

22. Jazieh AR, Khalil M. Hematologic complications of alternative remedies. Int J Hematol 74: 405-408, 2001.

23. Borum ML. Fulminant exacerbation of autoimmune hepatitis after use of Ma Huang. Am J Gastroenterol 96: 1654-1655, 2001.

24. Nadir A, Reddy D, Van Thiel DH. Cascara sagrada-induced intrahepatic cholestasis causing portal hypertension: case report and review of herbal hepatotoxicity Am J Gastroenterol 95: 3634-3637, 2000.

\section{Correspondence}

Dr. Gamze Gököz DOĞU

Pamukkale Üniversitesi Tip Fakültesi

Medikal Onkoloji Anabilim Dalı

20200 Kınıkl, DENIZLi / TURKEY

Tel: (+90.258) 4440728 / 5142

e-mail: ggd2882@gmail.com 